Article

\title{
Transformative Policies for the Social and Solidarity Economy: The New Generation of Public Policies Fostering the Social Economy in Order to Achieve Sustainable Development Goals. The European and Spanish Cases
}

\author{
Rafael Chaves-Avila ${ }^{1, *(1)}$ and Juan Ramon Gallego-Bono ${ }^{2}$ (D) \\ 1 Applied Economics Department \& IUDESCOOP, University of Valencia, Avda Tarongers, \\ 46022 Valencia, Spain \\ 2 Applied Economics Department, Faculty of Economics, University of Valencia, Avda Tarongers, \\ 46022 Valencia, Spain; Juan.R.Gallego@uv.es \\ * Correspondence: Rafael.Chaves@uv.es; Tel.: +34-963828428
}

Received: 18 April 2020; Accepted: 11 May 2020; Published: 15 May 2020

check for updates

\begin{abstract}
The United Nations Agenda 2030 has recognized that Social Economy (SE) entities play an important role in achieving the Sustainable Development Goals (SDG). In order to maximize the impact of the SE, governments have recently deployed new policies regarding these entities. The objective is to understand the context of policy change that has allowed these policies to emerge, their main characteristics and the critical factors in their construction and implementation. Successful policy cases in Europe and Spain have been studied. Qualitative data have been collected through key policy documents, experts, and focus groups. As a main finding, the study shows that this new model of policies exhibits the following features: it focuses on transformative change, follows the public-community partnership governance approach and the mainstream approach in the sense of a broader policy context, and finally, it is innovative in terms of means and of complex systematization of strategies. Difficulties in the implementation of the partnership approach, in the deployment of the policy-mainstreaming approach, and in the acceptance of the SE framed by all policymakers, SE representatives, and government staff, and constraints in financial endowment are the main critical factors in the implementation of these policies.
\end{abstract}

Keywords: Social Economy; public policies; cooperatives; sustainable development; ecosystems; local development; social and solidarity economy policies

\section{Introduction}

Cooperatives, as well as civil society organizations and philanthropic organizations, all of them entities that make up the Social Economy [1], play a major role in achieving the Sustainable Development Goals (SDG) of the UN 2030 Agenda, as is stated in the Resolution (A/RES/70/1) of the United Nations General Assembly Transforming Our World: The 2030 Agenda for Sustainable Development [2]. This UN 2030 Agenda is a worldwide road map, conceived as a transformative change [3], geared towards a hard new social and economic development model that addresses the main challenges of our world, from pandemics and disasters [4] to poverty and the rise of inequalities, climate change and environmental issues, digital and artificial intelligence revolutions, and imbalances in governance and financial systems.

Recognition of the role of the Social Economy in the UN 2030 Agenda is largely based on scientific evidence. Indeed, the literature has extensively studied and proved the social and economic value 
added and impacts of the Social Economy [5-9] and the direct relation between these functions and the SDG [10-16].

In order to maximize the impact of the Social Economy (SE) on SDG, governments must deploy extensive and effective public policies fostering the SE (PPFSE). This is what the UN 2030 Agenda states explicitly.

Currently, PPFSEs are a new public policy field for studies and practices. In fact, since the beginning of the last decade, around the world, at the international level as well as at the national and local levels, a new generation of political discourses and practices on PPFSEs has emerged. Examples of this range from the United Nations and the European Institutions to the Global Social Economy Forum (GSEF) and International Center of Research and Information on the Public, Social and Cooperative Economy (CIRIEC), two alliances of governments and community stakeholders and policymakers that are aligned with SE promotion. Furthermore, the scientific literature focused on SE and public policy issues has increased. It has studied PPFSEs in countries such as France, Australia, Poland, the USA, Canada, and Spain [17-20] and in continents such as Europe and America [8,21-24]. Nevertheless, these studies have a partial perspective; they focus on 'families' inside the SE, such as cooperatives and the nonprofit sector, or they address sectoral/vertical policies. More recently, other studies have focused on the policies promoting SE in contexts of economic crisis and austerity policies [25-27]. However, the new wave of PPFSEs in this new worldwide challenge context has received little attention from the scientific literature. Firstly, there has been a notable lack of attention paid to the change in the framing of these policies that has facilitated their deployment in many regions and countries by a new generation of policymakers. Secondly, no attention has been paid to the features and limits of these new policies. In this paper, we will focus on both issues, the frame change and the new wave of PPFSEs. Our starting hypothesis is that it is a new model of public policy, which we will call transformative policies for the social and solidarity economy (TPSSE).

The aims of this paper are to answer the following four research questions: What is the policy change context for the emergence of these new PPFSEs? What are the features of the new wave of PPFSEs deployed? What are the differences between these new TPSSEs and the traditional PPFSEs? Could a transformative model be considered as a new model? What are the limits and challenges of these new TPSSEs?

The paper is organized as follows. Firstly, the theoretical framework is briefly outlined, and then the materials and method of data collection used are explained. The context of the policy change that enabled the PPFSE is then explored. This is followed by a study of TPSSE cases in Europe and Spain, looking specifically at their key characteristics according to the theoretical framework, and comparing them with the 'old' PPFSE. The critical factors in the construction and implementation of these policies and their future implications are then analyzed. Finally, the conclusions are presented.

\section{Theoretical Framework}

SE has a value system that guides its behavior and gives it the potential for transformative change [1]. The EU is probably the entity that offers the clearest narrative coverage in favor of TPSSEs, when it defends that SE should imbue the entire economic system with its values. The need to consider a new model of development, a more egalitarian, participatory, inclusive, and sustainable one, would lead to broadening the scope of SE [28].

Through a series of positions taken by the multiple actors and institutions mentioned above, SE has found-or is being given-a more relevant role, to the extent that this framework of transformative change for politics is somehow taking on board the failure and inability of neoliberal growth models and austerity policies to address the serious problems affecting humanity. In this regard, the document "Transforming our World: the 2030 Agenda for Sustainable Development", is particularly noteworthy, as discussed above. In fact, by placing the need for an integrated or comprehensive approach at the heart of sustainable development and the goals for achieving it, SE will become vitally important not only for the development of a participatory, inclusive, and equitable approach, but also for the 
environment, especially through the importance and territorial anchorage of SE [29]. Therefore, sustainable development, in general, is of vital importance and with it, Social Economy is an essential tool to achieve some of the SDGs. This has created a general framework or narrative in favor of SE. We can expect this narrative to have a significant influence on the way in which SE gains greater prominence as an important instrument and lever of public policies to achieve various objectives.

The kind of values derived from the transformative framing that seems to be currently establishing itself in society are much closer than in the past to the values and principles that have always been promoted by cooperatives and SE. These are the principles of democracy, participation, concern for the community, priority for people, and work over capital, etc. Moreover, transformative framing does not only offer support to cooperatives, it also gives a boost to a whole set of non-market entities in the SE. These entities are essential for the values of inclusive and participatory development to penetrate society and for the effective realizations embodying these values to become a reality [3]. In this way, new areas of complementarities emerge in the new framing between non-market entities of the SE (associations, etc.), with which the third sector sometimes identifies, and market entities (cooperatives, mutual societies, etc.). In fact, the former can provide representation and knowledge of the problems of people in groups that face special difficulties, which allows to inject a different perspective into the economic system when it comes to tackling problems of employment, growth, and economic development, etc. In addition, this effective realization within the productive system finds a privileged place in the cooperatives and other market entities of SE.

This last process is due, on the one hand, to the fact that the latter entities operate in the productive system, with the potential influence that this entails on the set of public and private entities that also act in this system. However, on the other hand, this is also because the market and non-market entities of SE share the same principles and values to a large extent, which favors proximity and communication between them. However, there is no guarantee that this communication will take place. For this reason, it is important to stimulate and encourage cooperation between them [21]. In fact, it could be argued that if there has not been a denser relationship between the market and non-market entities of SE until now, it has been because the dominant values in dominant framing created a certain specialization effect, or even a fragmentation effect, between both types of entities. Perhaps it could be said that with the previous framing (where the economic factor is essentially separated from the social and environmental ones), the non-market entities of SE are focused on solving the problems of specific groups, while the market sector of SE operates in the productive system but with criteria that prioritize people and communities over profits and capital. On the other hand, in a framing that places participation and inclusion at the heart of sustainable development, new spaces of complementarities and synergies arise between both types of entities.

Several concepts and theories have shed light on the context of policy change in the field of public policies fostering SE. The first element is the concept of frame. Schot and Steinmueller [3] define frame as "interpretations of experience, ordering of present circumstances and imaginations of future potentialities that create the foundations for policy analysis and action and shape expectations concerning potentials and opportunities. They influence people's imaginations; they also extend beyond the public policy sphere to influence the mobilization and activities of nongovernmental organizations as well as the private enterprise sector" (p. 1554). In the same theory of frame, according to Rao and Greve [4], frame is a meta-communicative device that defines the parameters to understand events. Frames "enable individuals to locate, perceive, identify, and label occurrences. If frames are mental schemes or assemblages, framing is the process by which individuals make sense of their world" [30] (p. 464). Framing is to assign meaning to events and facts in order to mobilize action. The concept of frame is close to the Bourdieu [31] concepts of habitus and symbolic capital, and the rules and values of Fligstein and McAdam in their theory of fields [32]. Both define the mind rules and values as the frame/social imaginary perceived and recognized by individuals and organizations in a territory or policy field. This social imaginary establishes political discourses and narratives, which provide templates for guiding policymakers when acting on public policies $[4,33]$. 
Moreover, "the emergence of a new framing does not necessarily replace existing framings. However, framings compete with one another for the imagination of policymakers and, ultimately, citizens. The legitimacy of rationales and arguments for particular policies and the actions that follow them are influenced by the prevalence and understanding of the framings" [3] (p. 1555). Think tanks are engaged in the production and dissemination of frames, helping them in policy arenas. Policy narratives do not need the support of scientific evidence, but if they have it, they are in a strong position to be disseminated.

Government public policy is conditioned and determined by frames. According to the theory of "strategic action fields" [32], different actors (including policymakers) of an ecosystem or field of strategic action (e.g., a policy field) interact with each other, influencing and shaping the order of that field. The interaction between such private, public, and civil society actors and their policy actions are based upon other factors such as the frame, i.e., on bearing in rules and values. According to Kingdon's [34] policy-making model, the three streams (problems, policies, and politics) depend precisely on such intangible, cognitive models. The policy change depends on scientific data and rationale (the problem stream), new policy solutions that are suitable to adopt (the policy stream) and, finally, changes in governments and in public opinion (the political stream). All of them are materializations of the frame.

For our analysis of policy change, four elements of the frame are considered. The first element is the political narrative and the recognition of the rationale for this intervention. The second is the rationale/justification for any policy interventions. The third consideration is the think tank that produces and carries out frames. The fourth and final element is relevant examples of policy practices that have already been deployed elsewhere. As an innovative public policy area, the transformative framing of TPSSEs needs a strong rationale, political narrative, and success case.

To make this theoretical framework operational, and at the same time to understand and model, policy change for a transformative framing of TPSSEs needs a wide recognition of its meaning, a strong narrative, a robust rationale, think tanks that disseminate and provide narrative in policy debates, and good experiences of TPSSEs that can be replicated.

The first piece of the new narrative on the SE is the recognition that it represents a major field of public policy, with its own delimitation and its functionality in the economic system. SE is significantly different from the public sector and from the private for-profit sector. This issue addresses, firstly, the SE conceptual challenge. In this regard, the contributions from the academic sector, with the CIRIEC-network scientific work, and from the SE movement, such as the umbrella Social Economy Europe, have been critical. These works have converged to form a common definition that has been used in European institutions official statements. Among them, we can highlight the definition of the Toia Report of the European Parliament [35]: "The social economy is comprised of cooperatives, mutual societies, associations, foundations, and other enterprises and organizations that share the founding characteristics of the social economy", of the EESC in its study, carried out by CIRIEC, the Social Economy in the European Union [36] and of the European Council in its conclusions (7.12.2015) on The promotion of the Social Economy as a key driver of economic and social development in Europe: "the social economy enterprises refer to a universe of organizations based on the primacy of people over capital and include organizational forms such as cooperatives, mutual societies, foundations, and associations as well as newer forms of social enterprises and may be regarded as vehicles for social and economic cohesion across Europe as they help build a pluralistic and resilient social market economy".

The second piece of the political narrative addresses the worth of the SE: narrative says that the $\mathrm{SE}$ has specific values and is a key driver for a transformative change of the economy as a whole. At the European level, the political discourse claims that the SE is "a key driver of economic and social development in Europe" (European Council) or a pillar of the European social model and a cornerstone of a sustainable socio-economic development (EESC), while at the international level, the United Nations stated that the SE plays a major role in achieving the Sustainable Development Goals of 
the UN 2030 Agenda, addressing the main challenges of our world, such as poverty, inequalities, environmental issues, digital revolutions, and governance and financial issues [1].

The third piece of the political narrative is the scientific rationale of the multidimensional social and economic value added and the role of the SE in societies, which underpin the narrative. Over the past three decades, the scientific literature has extensively studied the SE, providing compelling arguments and empirical data for an evidence-based policy on the SE. Several scientific journals such as Annals of Public and Cooperative Economics, Voluntas, and others, as well as international studies, such as [37-40], have studied the different contributions of the SE to combat social exclusion and poverty, such as cooperation development, the insertion of labor to combat social exclusion, local development, and the provision of welfare services.

Two major groups of theoretical frameworks that reveal the 'good parts' of the SE have been developed by literature. The first group argues that the SE is a solution to institutional failures, as well market failures and public failures. The second group argues that the $S E$ is a response to system failure. Both rationales are currently complemented by a third rationale based on the capacity of the SE to provide transformative change. In the first group, we can find rationales based on the institutional failures approach [41,42], where non-profits, as entities belonging to the SE, have a greater economic capacity to supply certain public and private goods than the government sector and private for-profit sector due to arguments such as the contract failure in private goods and the heterogeneity of the demand of public goods. Another theory behind the institutional failure approach is the SE externalities theory. SE entities generate positive externalities in many areas [43], where the private for-profit sector generates negative externalities, such as financial and social exclusion [1]. The second rationale, the SE system's regulatory function approach, argues that the SE fulfils three fundamental roles in economies: regulating the supply of goods and services, regulating the labor market, and regulating the financial markets. The explanation is based on their system's roles of extending, replacing, and complementing, providing new responses and social innovation through innovation in products, processes, and forms of organization and involving citizens, workers, and users [44-49]. The third SE rationale is based on the capacity of the SE to address the main societal challenges through transformative change. Social utility, social impact, and the capacity to develop social capital, citizen engagement, and civic values are fundamental factors in this approach, where the worth of the SE is more than strictly economic but also social and political [5-7]. This latter approach directly addresses the SDG agenda challenges.

The fourth piece concerns the think tanks. Since the beginning of the last decade, many international institutions and organizations have disseminated SE political discourse through sharing information, direct diffusion of information, and building networks and alliances in order to coordinate and to help the SE narrative in policy debates. These entities are think tanks engaged in the production and dissemination of SE meanings, frames, and beliefs.

At the European Union level, the 'Social Economy Category' of the EESC, the 'Social Economy Intergroup' of the European Parliament and the Groups of Experts on Social Economy and Social Entrepreneurship (GECES) of the European Commission are the main advocate public institutions that have defended the policy discourse based on the recognition of the SE as a major policy field, its important social and economic contribution, and claiming for public policies fostering the SE. As mentioned before, the European Council has taken a stand on this issue in a major statement: The promotion of the Social Economy as a key driver of economic and social development in Europe [50]. The European parliament, through the official statement 'Toia Report' [35], and a more recent public hearing, several official opinions of the EESC and of the European Committee of the Regions are also in this political line [36]. The reports and activities of GECES have also had a high impact on disseminating mainstream SE perspectives in European policy debates.

At a global level, the United Nations, firstly, after approving a resolution on the recognition of the role of cooperatives in social development urging governments to put in place promotion policies set up the UN Inter-Agency Task Force on Social and Solidarity Economy (UNTFSSE) in 2013. Its aim is to bring together UN agencies and other intergovernmental organizations with a direct interest 
in the SE as well as umbrella associations of international social and solidarity economy networks. Its position paper Social and Solidarity Economy and the Challenge of Sustainable Development [10] was key for the recognition of the role that SE plays in the SDG [2]. The International Labor Organization also adopted a recommendation on the promotion of cooperatives (Recommendation 193/2002). The OECD has contributed to this political discourse with studies $[20,51]$ and has organized seminars. Local governments around the world built an international network in 2013, together with umbrella and civil society organizations, named GSEF, which is a global network committed to the dissemination of the same political discourse of the promotion of the Social Economy as a means to achieve a transformative, inclusive, and sustainable development (www.gsef-net.org). In other continents, other international organizations such as the Southern Common Market (MERCOSUR) Social and Solidarity Program in Iberoamerica have adopted similar positions.

At the national and regional levels, an increasing number of governments throughout Europe have positioned themselves in favor of PPFSEs [52].

Scientific networks, umbrella organizations, and many other civil society networks have also worked and forged alliances and network activities to help mainstream SE perspectives in policy debates. International SE scientific think tanks include the CIRIEC network, the Iberoamerican Observatory on Cooperatives and Social Economy (OIBESCOOP) network, the EMES network, and the United Nations Research Institute for Social Developement (UNRISD) network. Social Economy Europe is perhaps the most active representative SE platform in Europe. Other active networks are GSEF and the Intercontinental network for promotion of social solidarity economy (RIPESS), and countless others at local and national levels that have been central in driving forward the SE as a new paradigm agenda [53].

In Spain, the CIRIEC-Spain network, an association of researchers, teachers, and SE platforms, such as CEPES, the national SE umbrella, and several civil society networks have forged the SE political discourse [27]. Spain was, in fact, the first country in Europe to pass a Social Economy Law (2011) and one of the first to approve a national government strategy for the SE.

The fifth and last piece is the real success cases of TPSSEs which can be replicated in other countries. This topic will be analyzed in the following section of this paper.

To understand and model the diversified government policies for the promotion of the SE, we use two theoretical approaches. First, the soft and hard policy framework developed by Chaves $[8,54]$. This framework identifies two major groups of policies: soft and hard. The aim of the former is to establish a favorable ecosystem, through institutional and cognitive policies, that enables the emergence and development of the SE. The ecosystem's institutional policies focus on the legal and economic frameworks, such as on the recognition of a specific legal status for the entities of the SE, e.g., through a Social Economy Law, the recognition of their capacity to operate, without any legal barriers, in any sector of economic activity, the recognition of their role as partners in public policy processes and civil dialogue and, finally, the establishment of specialized governmental bodies within the public administration to supervise and promote the SE. Cognitive policies aim to increase visibility, training, and specialized research in SE. Hard policies act directly on SE entities by supporting both the supply side, promoting their economic competitiveness in the different areas of the value chain (i.e., financing and consulting), and the demand side, favoring their access to public markets, such as with the inclusion of social clauses in public procurement.

We use the policy framework of Utting [55] to analyze the PPFSE institutionalization and sustainability models. It considers four dimensions: governance, mainstreaming, public policy means, and institutionalization. The governance dimension addresses the nature of the involvement of key stakeholders in the policy formulation and implementation processes. Utting claims that a major feature of transformative policies is their deep and innovative civic participative governance. The mainstreaming dimension addresses the challenges of the introduction of SE policies in a broader policy context, considering both the general and vertical policies. A major issue to consider is the degree of penetration, coherence, and complementarities among policies. Improving a common 
framing environment and efficient coordination among the different policy areas and institutions is crucial. The public policy means dimension refers to the instruments used to design and implement PPSSE. The institutional capacity of the government bodies to effectively implement political discourses and policy objectives, the biases of technical staff, and the innovations in tools are all elements to be considered. Finally, the institutionalization and sustainability dimension refers to the challenge facing the PPFSEs to be sustainable and constant over time, avoiding the political ups and downs.

\section{Materials and Methods}

This article focuses on public policies aimed at the SE, a third economic sector located between the public sector and the private for-profit sector $[52,56]$. SE is considered in this paper as a new major field of public policy, but it is made up of entities and enterprises that are themselves subfields (such as cooperatives and social third sector organizations) and are part of fragmented sectoral public policies such as labor, agriculture, and social policies. SE is a concept well established in scholarly literature, in the European legislation, and in official statements of the United Nations (UN) and of European institutions such as the European Commission, the European Economic and Social Committee (EESC), and the Committee of Regions [36]. In this paper, we use the concepts of Social Economy (SE) and Social and Solidarity Economy (SSE) interchangeably as they are very similar. The period analyzed is 2014-2018, which corresponds to the period after the economic crisis in Europe and of the deployment of a new wave of government public policies at both national and sub-national levels in Europe [52].

This paper is based on empirical research undertaken as part of three research projects carried out in recent years: (1) Best practices of public policies fostering SE in Europe after the economic crisis, named the EESC-CIRIEC study and funded by the EESC; (2) Public policy fostering SE in Barcelona City, funded by the UNRISD; and (3) The new public policies fostering SE in Spain, funded by the Valencia regional government.

\section{Data Collection}

To collect the information, a variety of primary and secondary data sources has been used. We first gathered key documents using websites of government bodies, research centers, and international organizations, i.e., official statements, legislations, official documents of governments, internal documents and articles from specialized media, as well as position papers of international actors, for instance, those specialized in SE, such as CIRIEC, GSEF, and the intercontinental network for the promotion of social solidarity economy (RIPESS). We focused on key policy documents as an embodiment of the international and national positioning as regards to SE. We then gathered, through the EESC-CIRIEC study, information from 89 national policy experts, representatives of umbrella organizations and policymakers responsible for the SE policy, from all of the $28 \mathrm{EU}$ Member States. Data were collected and analyzed in 2017-2018. For each key informant, a questionnaire sent by email was used to collect data and qualitative information (see in Appendix A). The questionnaire covered nine topics, including the legal framework of the SE in each country, public funds and finances, main government policies deployed, and barriers in the development of the SE. Key policy documents were also provided by these national experts of the EESC-CIRIEC study.

In the second stage, twenty-one in-depth case studies of 'best cases of public policies' were conducted. The second stage of the study involved fifteen people, most of whom were members of the study's expert committee, and some of whom were members of the EESC and others of the European Commission and the European Social Economy Platform. They came from ten countries: France, Romania, Italy, United Kingdom, Bulgaria, Hungary, Portugal, Belgium, Poland, and Spain. Some countries had more than one case study, such as France and Spain. For the European Union PPFSE cases, national experts' inputs in the EESC-CIRIEC study and two focus groups were used. The focus groups included members of the SE category of the EESC and experts of the international scientific commission of CIRIEC. For the Barcelona, Madrid, and Valencia cases, semi-structured interviews with policymakers and SE networks representatives were conducted between June 2018 
and September 2019 to get in-depth information on topics regarding government policy fostering the $\mathrm{SE}$ in the period studied. In addition, for the case of Barcelona, two focus groups were conducted with government representatives and stakeholders' representatives of the SE platforms.

\section{Results. The New Generation of Public Policies Fostering the Social Economy}

\subsection{The New Generation of PPFSEs through the Typology Approach in Europe}

For decades, European countries have included different types of entities and enterprises belonging to the SE in their fragmented sectoral and vertical government policies. Social policies of the welfare states have, for instance, incorporated third sector associations and NGOs; agricultural and rural development policies have included farming cooperatives; active labor policies aimed at reducing social and labor exclusion have included workers' cooperatives and work integration social enterprises; territorial planning policies, urban regeneration, housing policies, and local development policies have included housing cooperatives and other local SE actors in their implementation, among other examples. However, they were never policies oriented to the SE as whole, nor were they comprehensive policies and they never included the SE at the core of the main policies [8,17]. A major change occurred during the last decade: A new generation of public policies has spread in Europe and around the world $[8,12,52]$.

In two studies carried out for the EESC, national experts identified forty-eight cases of significant public policies or 'good practices' deployed in different European countries and aimed towards Social Economy. Of these cases, around twenty were selected for in-depth study, in order to be a reference that could be replicated by other national and regional governments. Case selection was based on criteria of diversification of instruments and policy objectives according to Chaves' typology [54]. Box 1 lists and classifies fourteen of these 'good practice' cases.

Box 1. Selection of best cases of public policies to promote Social Economy in Europe, 2012-2016. Source: based on [52] p. 11.

Measures aimed at the legal form as a private player:

1. Law on Social Economy (Romania)

2. Agreement for the solidarity enterprise of social utility (France)

Measures aimed at recognizing SE enterprises as policymakers, an interlocutor in the public policy processes:

3. State Committee for SE Development and Incorporating SE into the mainstream public policies at the national and regional level (Poland)

4. Social Economy Europe (EU), the EU-level representative organization of the SE

5. Territorial clusters of economic cooperation

Measures focusing on raising awareness and spreading knowledge of Social Economy:

6. The «Concept» and Social Economy Action Plan (Bulgaria)

Measures promoting training in Social Economy:

7. National agreement between Education Ministry and Pupil cooperatives networks (France)

Measures promoting research on Social Economy:

8. University research/teachers' network (France and Spain)

Measures focusing on access to funds:

9. The European Social Fund (EU)_EaSI EuSEF

10. Entrepreneurship funds: Brasero financial tool (Belgium)

Measures focusing on business support (consultancy, networking, incubators, mentoring, etc.):

11. SE platforms at the national level: CNCRES, CEPES, and CEPS (France, Spain, and Portugal)

Unlike the first generation of policies aimed at Social Economy, where instruments were mainly budgetary and based on tax benefits, the new generation of PPFSE presents a more diversified typology. 
It has particular impact on some areas such as, firstly, the legal and cognitive recognition of this public policy space, the articulation of mechanisms for social dialogue and public-community participation in public policies, the greater complexity and systematization of policies through wide-ranging strategies and plans, the establishment of favorable ecosystems based on technical and financial support entities and instruments and, finally, preferential treatment for SE entities as suppliers to public administrations.

The main objective of the first group of policies is to include Social Economy as a major new public policy area in institutional frameworks. Through legal measures, it consolidates institutionally the concept of Social Economy as a large third sector located between the public sector and the for-profit private sector [56]. This sector requires a holistic conception of public policy to address it. These policies have materialized in the new national legislation on Social Economy passed over the past decade in the following countries: Spain, National Law 5/2011 on the Social Economy, Greece Law 4430/2016 on Social and Solidarity Economy (2016), Portugal National Law 30/2013 on the Social Economy, France National Law 2014-856/2014 on the Social and Solidary Economy, and Romania Law 219/2015 on the Social Economy. There have also been regional Social Economy laws (in the Belgian regions of Wallonia, Brussels, and Flanders), and laws with similar names and content such as social enterprises [57], like the Netherlands' Law on Social Enterprises (2012), Luxembourg's Law 2016 regarding the creation of companies with a social impact, and the Riforma del Terzo Settore in Italy in 2016. Finally, several bills on the subject are underway in other countries, and other institutional initiatives, such as systems of accreditation, have emerged in this period, revealing an increasing interest in this field among governments. The French Agreement for solidarity company of social utility is among these accreditation systems. Both the French Agreement and the classifications of entities made by the Italian Riforma legally delimit the areas considered of special socio-economic interest and give them preferential treatment in the policy of promoting SE.

A second group of new-generation policies are those in the cognitive field. They aim to implement the SE framework in society, in the education and research system, and in the SE sector itself. Measures 6, 7 , and 8 indicated in Box 1 refer to this type of policy. The "Concept" and Social Economy Action Plan of Bulgaria intends to make this public policy area visible to its own public administration, to society and to the SE sector. The French National Agreement between Education Ministry and Pupil cooperative networks intends to introduce the creation of Social Economy contents in the entire educational field, so that its values and forms of entrepreneurship are accepted and understood from adolescence to the university level. Promoting research on the Social Economy and generating discourse and stories, through events, conferences, master's degrees, networks, and doctoral teaching, contribute to extending and strengthening the vision (frame) and the social imaginary related to Social Sconomy.

A third group of policies refers to governance, development, and implementation. The preferred option is to involve civil society and SE actors in the co-construction and co-production of policies, instead of these being conceived solely from public administration. The concept of partnership between government, SE, and other stakeholders ensures that real needs and priorities are met. The deployment of mechanisms for social dialogue and public-community participation in public policies is a common feature, in some formalized cases, such as the State Committee for Social Economy Development and Incorporating SE into the mainstream public policies on the national and regional level in Poland (see Box 1), the Conseil Supérieur de L'Economie Sociale et Solidaire in France, or the CASES Cooperativa António Sérgio para a Economia Social—public interest cooperative in Portugal. These are participative and consultative bodies that involve SE platforms with government representatives in policymaking processes. Other forms of partnership and co-decision have also been implemented on a more informal basis.

The fourth group of new-generation PPFSEs includes strategies or plans of broad scope, conceived with greater complexity and technical systematization than first-generation policies. They constitute major agreements between different actors, mainly between the government and SE representatives, but also include other civil society actors such as trade unions, grassroots associations, and universities. They include over a long-term period a stable relationship between the actors, 
stable funding frameworks, strategic objectives and fields to develop, and new means and evaluation indicators [52]. Strategies have been deployed at both state and regional levels. Among the former are the Action Plan for the Social Economy (2014-2015; 2016-2017) of Bulgaria, the National Programme for the Social Economy of Poland, the Strategy for the Social Economy of Spain, the Multi-Annual Programme to Support Work Integration Social Enterprises of Sweden, and the Strategy for the Development of Social Entrepreneurship in the Republic of Croatia (2015-2020). Among the regional cases, we find those developed in various cities and regions of Spain, such as Andalusia, Murcia, Madrid, the Balearic Islands, Barcelona, Valencia, and Galicia. Three of these cases are analyzed in depth in the following section.

A fifth group of policy innovations refers to the establishment of sets of technical, informational, and financial support instruments in the territory; these form favorable ecosystems for the creation and development of Social Economy entities [58,59]. Business support entities for consultancy, networking, incubators, mentoring, and financing have been created. Some of them are public bodies that allocate funds and services. They depend on new national government bodies, such as the Ministry for Social Economy (e.g., in France, Luxembourg and Spain) or sub-ministerial bodies, such as the Secretary of State for Dialogue with Civil Society and Social entrepreneurship within the Prime Minister's Cabinet (Slovenia) or the Social Economy and Public Benefit Department within its Ministry of the Family, Labor, and Social Policy in Poland. In other cases, this business support network is financed by public funds but operated by SE private entities or platforms. This is the case of the cooperative and social enterprise federations and associations throughout Europe. Finally, hybrid entities have been created, such as the Agences Conseil for the Social Economy created by the Belgian Walloon regional government, which are development agencies coordinated at the regional level in order to boost SE organizations [20,52]. Another innovation in the ecosystem instruments is the French Regional economic cooperation clusters (PTCE) [60]. It exhibits accurately the features of the TPSSE model ((N.Richez-Battesti, French expert, personal communication, October 15, 2016). This case of public policy is explained briefly in Box 2.

Box 2. The territorial clusters of economic cooperation case.

The territorial clusters of economic cooperation (Pôles Territoriaux de Coopération Economique) were recognized by
the 2014 French Law on the social and solidarity economy as one of the new tools to promote this socioeconomic
sector in France. They consist of alliances among SE entities, private firms, research and training centers,
and governments at a local or regional level in order to implement a sustainable partnership strategy to address
jointly and innovatively strategic issues of their territories. SE entities are leaders or partners of these clusters.
The projects carried out by the 'Poles' are mostly financed by public funds and elected under their socially,
environmental, or technologically innovative economic criteria.
This public policy presents the features of the TPSSE: it focuses on transformative change, addressing local
territorial development challenges in activities such as labor issues, sustainable agriculture, and creative
industries; it follows the public-community partnership governance approach, involved in a stable network
and at the local level public, Social Economy, and private actors; it is transversal, in the sense that 'Poles'
projects are linked to different kind of public policies, and finally it is in itself an innovation in means and in
governance. Two practical cases are PTCE Figeacteurs in Figeac (http://www.figeacteurs.fr) and Kaleidoscoop
PTCE in Strasbourg (http://www.kaleidos.coop/).

Finally, a sixth group of PPFSEs that has emerged in the last decade includes the measures aimed at easing SE access to public markets, with the introduction of social criteria in public procurement [61]. This was historically prohibited due to the mainstream frame in public markets that protects free competition. The review of the EU regulations on public procurement in 2014 (Directives 2014/23, 2014/24, and 2014/25) has profoundly changed this traditional mainstream discourse, by now facilitating the access of SE entities to public sector supplier status. As a demand-side policy to boost the SE, it has opened up new government means, such as reserve markets and the introduction of social clauses in the procedures for awarding public contracts. As it is compulsory for the member States to adapt their laws to comply with the mentioned Directives, several countries have approved new laws in the last 
few years, such as the Spanish public contracts law of 2018 and the Italian Reform of the Third Sector (Riforma del Terzo Settore) of 2017.

\subsection{The New Generation of PPFSE through the Territorial Approach in Spain: The Valencia, Madrid, and Barcelona Cases}

In Spain, following the regional and local elections of 2015, many sub-national governments have promoted a new generation of policies to foster Social Economy. These are the cases of the regional governments of Navarre, Murcia, the Balearic Islands, Galicia [62], and Valencia, as well as the local governments of Barcelona, Madrid, Zaragoza, Seville, Granada, and Gipuzkoa [63]. It is also important to highlight the government of the region of Andalusia, which in the first decade of this century, innovatively implemented the Andalusian Pacts for the Social Economy, an experiment in this new generation of Social Economy policies. We selected three of these cases for in-depth analysis: the first two because they correspond to the country's largest cities and are international references in this field; and the Valencian Government as a regional example, promoted by socio-political forces similar to the previous two.

The three cases bring together, at least initially, the characteristics of TPSSEs: the partnership approach to the construction and production of this policy and its systemic transformative perspective; the conception of SE as a new field of public policy, endowed with a new discourse, transversal, and can be integrated in the multiple existing sectoral public policies; the systematization and holistic nature of this policy; and, finally, political innovation in terms of objectives and instruments.

\subsubsection{The Valencian Case}

In 2015, after more than twenty years of conservative governments, a coalition of left-wing political parties took office in the region of Valencia and signed a global agreement for socio-economic transformation, "l'Acord del Botànic". This agreement includes a medium-term strategic plan for the transformation of the Valencian economic model [64]. This plan is structured around 10 strategic lines for the transformation of the Valencian economy, one of which is strategic line 5, "Promoting the creation of sustainable employment and social economy". There is therefore a consensus among the political forces for the deployment of a TPSSE in the region, which would conceive Social Economy as a new field of public policy.

In October 2017, the Valencian Cooperativism Council (Consejo Valenciano de Cooperativismo), made up of the Consell and the Confederació de Cooperatives, approved the 1st Biennial Plan to Support and Promote Valencian Cooperativism (2018-2019), called 'Fent Cooperatives' [65]. This policy is aimed at Cooperatives, a sub-field of the Valencian Social Economy [66], and not at the Social Economy as a whole, making it different from the cases of Madrid and Barcelona. The Fent Cooperatives Plan is also aligned with other public policies, such as the Europe 2020 Strategy, the rural development plan, the Valencian Territorial Strategy, and the Valencian Entrepreneurship Plan, showcasing its mainstreaming perspective.

The strategic goal of the 'Fent Cooperatives' Plan is to improve the competitiveness of Valencian cooperatives based on four main areas: achieving social, economic, and environmental sustainability; increasing stable and quality employment; making progress in the equal representation of women and young people in corporate responsibility areas; and extending the values and principles of the cooperative model to the rest of the Valencian business fabric. Within the framework of these four main areas, the Plan is structured into six major strategic lines: Sustainable Business Development; Corporate Development; Employment and Territorial Development; Financing of Cooperatives; Dissemination, Training and Cooperative Research; and finally, Institutional Consolidation. These six strategic lines of the Plan are structured into 27 Strategic Objectives, 72 Initiatives and 101 Actions or specific measures (see Table 1). 
Table 1. Summary of the Valencian Community's 'Fent Cooperatives' Plan, 2018-2019.

\begin{tabular}{l}
\hline Line 1: Sustainable Business Development \\
\hline Strategic Objectives \\
\hline 1. Improving the competitiveness of the cooperative enterprise \\
2. Internationalization of Valencian cooperatives \\
3. Cooperative business growth oriented towards people, efficiency, and sustainability \\
4. Meeting the needs of citizens, professionals, and SMEs through cooperativism \\
\hline Line 2: corporate development and development of corporate social responsibility \\
\hline 1. Reinforcing cooperative values through the promotion of CSR practices \\
2. Development of instruments to articulate participation and business efficiency \\
3. Coordination of actions to promote cooperativism with actions to remove gender inequalities \\
\hline Line 3: employment and territorial development \\
\hline 1. Creation of quality employment: Stimulating cooperative entrepreneurship \\
2. Participation of cooperatives in local development \\
3. Definition of protocols and codes of cooperative action in the field of employment \\
\hline Line 4: financing of cooperatives \\
\hline 1. Recovering investment and cooperative business financing \\
2. Strengthening financial management in cooperatives \\
3. Adequate channelling of financial resources for the co-operative movement \\
4. System of guarantees and endorsements \\
5. Promotion of Valencian credit cooperatives
\end{tabular}

Line 5: dissemination, training, and cooperative research

1. Management model of cooperative companies

2. Promotion of dual vocational training in cooperatives

3. Coordination of training actions in the field of cooperative identity and culture

4. Dissemination of the cooperative business formula and extension of cooperative values to the rest of the business fabric of the Valencian Community

5. Promotion and enhancement of cooperative training at all levels of education systems

6. Boosting cooperative research and promoting knowledge transfer

Line 6: institutional consolidation

1. Strengthening of the Valencian Cooperativism Council

2. Consolidation and promotion of policies for the promotion and dissemination of cooperativism

3. Promotion of associationism and the cooperativism in socio-economic forums

4. Promotion of public-private collaboration in the provision of community services

5. Coordination of administrative actions of support measures for cooperatives

6. Provision of means for the implementation of a new organization and operation of the Registry of Cooperatives

$$
\text { Source: 'Fent Cooperatives' Plan [65]. }
$$

The Plan specifies the Body responsible for the implementation of each initiative and the budgetary amount allocated. Finally, the Plan includes a strategy for monitoring and assessing results, as well as an evaluation after two years; however, it does not include systematic evaluation indicators.

The Valencian Plan has some differing elements when compared to the other two cases under study. The first is the definition of the scope of the TPSSE. Despite having a favorable institutional environment, a favorable social imaginary framework, and a political mandate aimed at setting up a TPSSE, the government finally opted to divide the policy into two sub-areas of Social Economy: one aimed at cooperatives, the Fent Cooperativas Plan; and the other aimed at the third social sector, which is covered by the new policy of inclusive social services in Valencia (Law 3/2019 on social services). One of the social agents, the representative platform of the cooperatives, is in favor of a "family" strategy that does not encompass the entire SE, conditioning the implementation of the TPSSE. This results in less participatory governance than in the other two cases under study, as it also excludes other agents both from university and from other areas of government, as well as 
other sectors of the Valencian SE. Secondly, one of the political parties in the government coalition, responsible for the TPSSE, opted to blur the state consensus on the political narrative linked to the Social Economy and promoted a new language, with 'neoconcepts' [67] such as the economy of the common good, social responsibility, social enterprises, and social innovation, with little presence or impact in this region to date. The orders for specific budgetary aid to these areas or the very Law $18 / 2018$, of 13 July, for the promotion of social responsibility, bring concreteness to this confusion. Last but not least, the 'Fent Cooperativas' Plan has a scarce budget line and human and material resources, which significantly limits the possibilities of its implementation.

\subsubsection{The Madrid Case}

After the municipal elections of 25 May 2015, a coalition of left-wing parties was elected to the government of the City of Madrid. Ahora Madrid, the main party, to which the mayor Manuela Carmena belongs, has political discourse, programmatic principles, relations and synergies with Guanyem Barcelona, the party that sponsors the other case of TPSSE analyzed below. The Ahora Madrid electoral program includes a section on the explicit promotion of the social and solidarity economy (SSE). This program, in addition to encouraging the creation of a specific body to carry out this public SSE policy, conceives the usefulness of SSE in multiple socio-economic areas, from employment and entrepreneurship to the management of community services and mobility. In October 2018, the Governing Board of the City of Madrid approved the Municipal Strategy for the Social and Solidarity Economy of the Madrid City Council for the period 2018-2025.

The Madrid SSE Strategy [68] is based on the participation of the representative entities of the SSE of Madrid, university experts, civil society, and technicians of the municipal government of Madrid. The working tool has been a report known as "Diagnosis of the SSE in the city of Madrid", a participatory process to identify the city's substantive needs and problems, and the co-design of public policies that respond to these needs, as well as a monitoring and evaluation system. Co-responsibility and shared leadership are at the heart of the entire strategy.

The preparation of the 'Diagnosis' report lasted a year, under the leadership of Madrid City Council's Economy and Finance Area and with multiple contributions from Madrid's civil society, from what they have come to call "the city's SSE sphere". In the process of drawing up the SSE Strategy, the agents that participated in the preparation of the Diagnostic Report were the following: staff from the City Council, university representatives and other experts, and representatives and people from different families of the Madrid SSE, according to Law 5/2011 on the Social Economy.

With a time horizon of 8 years, the Strategy is structured around 4 main axes of action, structured around 8 strategic objectives, 18 lines of action, and 69 actions. It also has 21 indicators (called Goals) for achieving objectives. The Strategic Objectives define the general mission of the City Council in relation to the SSE and are expressed in the major general objectives of the Strategy. These, in turn, are structured into the Axes, which are the Strategy's priority work areas. The 4 axes are: (1) the creation of territorial ecosystems (neighborhoods-districts) of the SSE, (2) the positioning of the SSE at the center of municipal policies, (3) the generation of knowledge and innovation for the development of the SSE, and (4) the creation of a comprehensive support system for the creation and strengthening of the SSE. The lines of action are the instruments that allow to achieve the objectives, while the concrete actions constitute the specific measures to be deployed (see Box 3). Financially, the Madrid SSE Strategy initially has a budget of 5.89 million euros, to which the resources of other areas and municipal policies with which the TPESS is hybridized must be added, given its cross-sectional nature. 
Box 3. Lines of action of the Madrid Social and Solidarity Economy (SSE) Strategy. Source: Madrid SSE Strategy [69].

1 Support offices for the creation, accompaniment, and financing of the SSE.

2 Actions for the creation and promotion of SSE in territorial ecosystems.

3 Support for the inclusion of particularly vulnerable people in SSE entities.

4 Raising awareness of SSE in formal education (primary and secondary education).

5 Creation of a specific area for research, documentation, innovation, and transfer in SSE.

6 Collaboration agreements with universities, vocational training centers, and other areas of innovation for the development of SSE pilot initiatives.

7 Municipal investment in innovative projects with high social impact.

8 Support for the development of entities with high technological value.

9 Training and awareness programme in SSE for municipal staff working in the city's socio-economic area.

10 Training program in SSE aimed at citizens who benefit from municipal resources for labor insertion.

11 Design of a communication program on SSE in the municipality.

12 Responsible public procurement and contracting.

13 Ongoing training and strengthening program to improve the competitiveness of SSE entities.

14 Support for the financing of SSE entities.

15 Support for SSE intercooperation processes.

16 Support for the transformation and transfer of commercial enterprises into SSE entities.

17 Coordination program between self-employed persons, community estates, limited liability companies, and other business formulas through SSE.

18 Promotion of SSE sector clusters and encouragement of participation in those promoted by the City Council.

The main contents of the axes of the Madrid SSE Strategy are:

Axis 1: Creation of territorial SSE ecosystems: Given the central nature of the region and the city's neighborhoods, the goal is to create favorable ecosystems for SSE, providing it with resources and spaces, in 4 large areas of the city of Madrid. This axis takes the form of the creation of multi-purpose territorial centers for the development of SSE. They aim to provide information, make the SSE and its achievements visible and co-create a narrative (discourse), providing advice as well as exchanging experiences. The Social Economy Offices have been a tangible achievement, as they provide advice on the creation, development, and funding of SSE entities.

Axis 2: Positioning SSE at the heart of municipal policies: This axis aims to introduce, in a cross-sectional and coordinated manner, the SSE-both in its conception and socio-economic vision and in its practice-in the different areas of the municipal administrative apparatus as well as in the policies of the different areas of government. "The SSE will be part of the symbolic universe of the City Council, both of the government team and its way of understanding the city, as well as of the civil service and/or employment staff of the municipality. It will also be part of the narrative that the City Council relays and communicates to the citizens of Madrid. The SSE will be present in the design and planning of public policies, as well as in municipal practice" [69].

Axis 3: Generation of knowledge and innovation for the development of SSE. From the transformative perspective of this policy, SSE is conceived as a vector of social and systemic innovation. It is conceived as a field for experimentation in the co-production of municipal policies, for the generation and exchange of knowledge geared towards change. The vision it defends is based on the active participation of various agents in this process: the University, the trade union movement, the social movements, the community initiatives, the Public Administrations, and the SSE organizations themselves, in the training, transfer, and development of spaces.

Axis 4: Creation of a comprehensive system of support for the creation and strengthening of SSE. This axis proposes lines of action to support the creation, consolidation, and improvement of the competitiveness of SSE business initiatives that have emerged in the city. This shall be done by means of all types of 'hard' supply policy measures: support, communication, funding, technical services.

The main weakness of this Strategy lies in the fact that it has hardly any material time to be implemented. The excessive time invested in developing the ambitious citizen participation process has been to the detriment of political times. To this, we can add the strong rejection by the municipal 
political opposition, who has not hesitated to deploy a counter-report addressing the media and the citizenry. Only a few months after the Strategy was officially approved, following the municipal elections of May 2019, there was a political shift towards a conservative government coalition that disrupted the Strategy's continuity: one of the first measures of the new municipal government was to dismantle the main municipal initiatives in favor of the SSE.

However, a specific co-participated action was being developed in parallel during this term: the project MARES of Madrid, which can be considered the other aspect of the actual deployment of the TPSSE in the city of Madrid. This is a European project coordinated by the Madrid City Council and eight entities of the Madrid SSE, framed within the European Commission's Urban Innovative Actions initiative and financed with ERDF funds. Therefore, in this case, the TPSSE has benefited from external financing, with European funds, for its deployment. The implementation period of this project takes place mainly during the term of Mayor Carmena's government, between November 2016 and October 2019. The Mares project can be seen as an experiment in the vision and lines of action envisaged in the Strategy.

Project Mares aimed to experiment with innovative ideas of a transformative nature to meet the challenges posed by European cities. It aimed to transform the city of Madrid through SSE [68]. The fields of action in which it develops its work are sustainable mobility, food, recycling, energy, and the social services or care sector. In addition to constituting vectors of transformation in these areas, with actions to raise public awareness of the need to apply more sustainable and viable production models to current urban challenges, it also aimed to generate new sustainable and quality production fabric. Its results include the incubation of 48 new business initiatives and the participation of more than 13,000 people in almost 1000 training and awareness-raising events.

\subsubsection{The Barcelona Case}

Similar to the previous two cases, the TPSSE of the city of Barcelona is promoted by the left-wing electoral coalition Barcelona en Comú, which won the municipal elections in 2015. SSE played an important role in the electoral program of the winning political parties. The new mayor chose an activist from the cooperative movement and the solidarity economy to lead municipal action in this area, and created an inter-institutional body, the Commissionat d'Economia Cooperativa, Social i Solidària de l'Ajuntament de Barcelona (hereinafter Commissionat), from which the TPSSE would be deployed. After a relatively short period of debate and citizen participation, the Pla d'impuls de l'economia social i solidària (2016-2019), hereinafter PIESS, was approved and began to be implemented. PIESS would have the decisive political support of the municipal government throughout its deployment, in addition to a significant budget allocation.

For the PIESS' policymakers, SSE is conceived as a powerful engine of socio-economic transformation that responds, in a systemic and public-community partnership manner, to the multiple problems, challenges, and needs of the city [70].

PIESS also embraces the participatory and partnership approach of co-construction and co-production of this public policy. In fact, shortly after the new municipal government was formed, the Commissionat - the leading and catalyzing body of this policy-undertook a participatory process to design this policy. This process involved various representatives of the families of the SSE in Barcelona, as well as experts and other people from civil society. It builds its own space for participation and dialogue on the SSE, known as 'participatory sphere of SSE policy'. This 'Sphere' will be central to the partnership preparation and application of this policy, which was previously unknown in Spain. A differential element with regard to the Madrid case is that the participatory process of policy design was not delayed in time and the aim was to begin implementation as soon as possible.

As for its contents, PIESS, like the other two cases studied, is systematized in a complex architecture of objectives, instruments, responsible bodies, and monitoring and evaluation indicators. It contains two major general objectives, 6 lines of work, 24 specific objectives, and 31 specific actions. The major objectives are the promotion of new initiatives and of the transformation of traditional companies into 
entities of the SSE and to strengthen existing SSE entities. The lines of work, as well as the main actions to be carried out during the period 2016-2019, are shown in Table 2. More specifically, the Plan contains various instruments for both hard and soft policies. These are (1) financial support instruments, such as budgets and public, private and public-private financing mechanisms; (2) cognitive support instruments, such as awareness and dissemination instruments, reports and statistics, as well as training activities; (3) technical support and advisory instruments, and support for innovation; (4) instruments to support access to public markets, such as public procurement and the social market; (5) unique and referential instruments; and finally, (6) instruments to support the creation and development of social and participatory capital, such as networks of entities, and shared facilities [70]. Many of the instruments applied, such as the social market or the projects for emblematic collective spaces, are political innovations, typical of a new transformative policy.

Table 2. Summary of the Pla d'impuls de l'economia social i solidària, 2016-2019.

\begin{tabular}{|c|c|}
\hline Objectives-Lines of Work & Instruments \\
\hline \multirow{3}{*}{ A. Support and training } & $\begin{array}{l}\text { 1. Provide technical support in comprehensive cooperative } \\
\text { management for SSE companies and entities. }\end{array}$ \\
\hline & 2. Training for promoter groups and city council workers. \\
\hline & $\begin{array}{l}\text { 3. Training and dissemination in educational centers and } \\
\text { universities. }\end{array}$ \\
\hline \multirow{3}{*}{ B. Financing } & $\begin{array}{l}\text { 4. Promoting ethical banking and credit unions as financing } \\
\text { tools. }\end{array}$ \\
\hline & 5. Specific subsidies from the City Council. \\
\hline & 6. Study for more favorable taxation of SSE. \\
\hline \multirow{5}{*}{ C. Intercooperation } & 7. Improving access to public markets (procurement, clauses). \\
\hline & 8. Social market, catalogue and map of SSE initiatives. \\
\hline & 9. SSE trade fairs, meetings. \\
\hline & $\begin{array}{l}\text { 10. Promotion of cooperative groups, platforms and 2nd level } \\
\text { entities. }\end{array}$ \\
\hline & 11. Network of municipalities and international networks. \\
\hline \multirow{3}{*}{ D. Communication and narrative } & $\begin{array}{l}\text { 12. Raising the profile and awareness of the SSE among citizens } \\
\text { and the media. }\end{array}$ \\
\hline & 13. Promotion of research on SSE. \\
\hline & $\begin{array}{l}\text { 14. Development of cognitive resources: outreach materials, } \\
\text { repertories, observatory. }\end{array}$ \\
\hline \multirow{2}{*}{ E. Equipment and resources } & 15. Transfer of equipment and public spaces to the SSE. \\
\hline & 16. SSE emblematic spaces (coopolis, etc.). \\
\hline \multirow[t]{2}{*}{ F. Territorialization and communityaction } & $\begin{array}{l}\text { 17. Integration of SSE in the policies of the City Council } \\
\text { (district policy, community services, etc.). }\end{array}$ \\
\hline & 18. Community management of services. \\
\hline
\end{tabular}
Source: Barcelona's SSE Plan (2016-2019).

In short, PIESS is a paradigm of TPSSEs. It brings together the specific features of this type of policy: the cross-sectional nature of SSE, the partnership approach, the transformative socio-political perspective, the mainstreaming approach, and political innovation in terms of instruments and the systematization of the strategy, in addition to the political will of the local government and the pragmatism of its promoting public body, the Commissionat [71].

Out of the three TPSSE cases studied in this article, PIESS has been the only one that has been subject of a (very recent) evaluation process. After 4 years of implementation, PIESS' main 
achievements have been its contribution to increasing public funding for the SSE, increasing the visibility and awareness towards the SSE both by the citizens and in the municipal administration itself, cognitively and organizationally structuring the field of SSE, and establishing a stable space for participation in the public policy of the Social Economy. The greatest achievement is that of having implemented a cross-sectional TPSSE.

However, due to its cross-sectional nature, PIESS has not been free of challenges in its implementation [71]. The first group of difficulties has been those internal to the administrative apparatus itself. These translate into difficulties in extending the discourse on SSE to the entire administration of the City Council and in integrating the SSE into the multiple political areas of work of the City Council. Other difficulties include bureaucratic problems and a lack of adaptation of the time frames for calls for proposals, as well as the granting of aid to the needs of the sector: "the operating rhythms of the local government and the SE sector are quite different, a major challenge is to adapt them" (Focus group with policymakers in Barcelona, October 22, 2019) The second group of challenges are those linked to the SSE sector itself, which was initially fragmented into its various 'families' (cooperatives, third social sector, mutual societies, etc.). It has encountered resistance to accepting discourses and strategies that are common to the SSE as a whole. These are difficulties inherent to the emergence of a new area of cross-sectional public policy.

As conditions for its success, PIESS has relied on two fundamental elements: on the one hand, the political will of the local government to carry out this policy, a will that has been expressed, among others, through generous budgetary support; and on the other hand, a catalytic, pragmatic, and dynamic agent, the Commissionat, as a public promotional body, and the participatory sphere of the SSE. The pragmatic vision in the implementation of PIESS was clear from the use of a short time horizon and simple, pedagogical, and involving documents [71].

\subsection{The New Generation of TPSSE Compared to the Classical PPFSE}

Following the analytical framework of [34] and Chaves and Monzón [52], we proceed to compare the first generation of SE promotion policies in Spain and Europe with the new PPFSE policies, taking into account the following variables: degree of complexity of the policy, nature of the policymakers involved in the preparation and application of the policy, technical conception, specific instruments, degree of integration of the policy in the general governmental policies, and evaluation of the policy.

\subsubsection{Characterization of the First Generation of Social Economy Policies}

Since the early 1980s, various policies to promote cooperatives and other Social Economy entities have been implemented in Spain and Europe [17,33,72-74]. Their basic characteristics were as follows:

Regarding governance, the policymakers were mainly the political leaders of the public administrations and their administrative apparatus. These policymakers, understood in a restricted sense, play a hierarchical leading role (top down, mono-policymakers) in the Social Economy policy (direct approach), both in its preparation and in its implementation phase. The involvement of Social Economy actors, sometimes through their representative bodies, and of other civil society actors was limited. We can speak of a hierarchical governance.

The policy conception of Social Economy was still vertical and restricted, and it was linked to the challenges of different sectoral policies (e.g., labor, agricultural, or social policy). In some cases, there was an incipient battery of measures to support Social Economy, but it had little integration with other sectoral and general government policies. It was located in adjacent, marginal, and poorly integrated sections of general policy. This can be explained in part by their low priority on the political agenda of these governments. The political discourse regarding Social Economy was not very solid yet, fragmented by families of the Social Economy, and its nature as a socio-economic transformation project was limited.

These policies can be categorized as fast policies, that is, policies whose adoption process is incipient, done in a short period of time and with little systematization, preparation, or evaluation 
of their contents. They were the first political innovations. Policy was designed by the central government, which sets the central guidelines for these measures, and it was implemented and managed by sub-central governments. There are few variations of these policies between regions due to the high degree of conditioning of the financing, which comes mainly from the European and central level. When the regional government had greater financial margin, it opted either to grant more financing to the same existing measures or to open new measures, similar to the previous ones [72].

From the perspective of the public policy instruments designed and implemented, this first generation is characterized by its technical simplicity-its importance lies in the budgetary amount available. The main features were the possibility of capitalizing unemployment benefit as a one-off payment when a cooperative or labor company is set up, and annual subsidies from the Ministry of Labor to create corporate employment in cooperatives and labor companies, for technical assistance, for investment, for the promotion and dissemination of the Social Economy, and for aid to representative structures.

The evaluation of the measures to promote this Social Economy policy was scarcely developed and, when it was carried out, it was done on the basis of quantitative criteria of effectiveness (number of jobs and companies created), efficiency, and relevance [72].

\subsubsection{Characterization of TPSSEs}

The second generation of Social Economy policies brings about a significant qualitative change from the first-generation policies (see Table 3):

Table 3. Comparison between first generation SSE policies and TPSSEs.

\begin{tabular}{|c|c|c|}
\hline Characteristics of the Policies & First-Generation Policies & TPSSE \\
\hline $\begin{array}{l}\text { Degree of complexity } \\
\text { of the policy }\end{array}$ & $\begin{array}{l}\text { Fast policies (simple, } \\
\text { not systematic). }\end{array}$ & $\begin{array}{l}\text { Systematic policies } \\
\text { (complex, systematic). }\end{array}$ \\
\hline $\begin{array}{c}\text { Nature of } \\
\text { policymakers involved }\end{array}$ & $\begin{array}{l}\text { Direct approach. } \\
\text { Policymakers in a limited sense. } \\
\text { Hierarchical governance. }\end{array}$ & $\begin{array}{l}\text { Partnership approach. } \\
\text { Policymakers in a broad sense, } \\
\text { with broad citizen participation. } \\
\text { Participatory governance. }\end{array}$ \\
\hline $\begin{array}{l}\text { Nature of policymakers in } \\
\text { implementing policy }\end{array}$ & $\begin{array}{l}\text { Direct approach. Policymakers in } \\
\text { a limited sense, mainly. }\end{array}$ & $\begin{array}{l}\text { Ecosystem approach. Policymakers in } \\
\text { a broad sense, with great involvement } \\
\text { in implementation. } \\
\text { Flexible governance. }\end{array}$ \\
\hline Technical conception of policy & Simple and budgetary devices. & $\begin{array}{l}\text { Holistic and strategic } \\
\text { approach to policy. }\end{array}$ \\
\hline Specific policy instruments & $\begin{array}{l}\text { First-generation instruments: } \\
\text { one-off payment, subsidies for job } \\
\text { creation, technical, } \\
\text { and investment; subsidies for } \\
\text { dissemination and to structures. }\end{array}$ & $\begin{array}{l}\text { Second-generation instruments: } \\
\text { PCTE, athenaeums, social promoters, } \\
\text { public procurement, coworking, } \\
\text { specialized training; activities carried } \\
\text { out by various actors. }\end{array}$ \\
\hline $\begin{array}{l}\text { Degree of policy } \\
\text { integration into general } \\
\text { government policies }\end{array}$ & $\begin{array}{l}\text { Sectoralized, poorly integrated } \\
\text { into major general policies. }\end{array}$ & $\begin{array}{l}\text { Mainstreaming approach. High level } \\
\text { of integration in general policies, } \\
\text { including centrality. }\end{array}$ \\
\hline Evaluation of the policy & $\begin{array}{l}\text { Quantitative criteria of efficiency, } \\
\text { effectiveness, and relevance. }\end{array}$ & $\begin{array}{l}\text { Quantitative and qualitative criteria, } \\
\text { including participation, } \\
\text { consistency and sustainability. }\end{array}$ \\
\hline
\end{tabular}

The construction process of these second-generation policies moves from a hierarchical and managerial approach (direct approach), where the main role is played by policymakers in their limited conception, to a broader approach of participation (partnership approach, multi-policymakers). They are designed with the active participation of the Social Economy sector and not fundamentally from the public administration responsible for that field. There is therefore a shift in policy approach 
from a top-down approach to a relational or co-production approach $[75,76]$. In increasing the participation of actors in the policymaking process, two elements must be considered: which social actors are invited to participate, and which participation mechanisms and spaces are used, whether they are institutionalized, newly created, or informal. The advantages of a partnership and relational approach are twofold: on the one hand, it achieves a better alignment of objectives, strategies, and measures with real needs and the problems on which to act; and, on the other hand, it achieves a greater involvement of the target reality itself, which results in greater effectiveness and a multiplier effect of the measures adopted.

This second generation of policies has overcome the marginalization, partiality, and sectoralizationif not 'ghettoization' — of Social Economy policies in general government policy and has become fully integrated into general policy. These second-generation policies tend to be approached from a mainstreaming approach, i.e., integrated and permeating the main general policies of governments, whether local or regional. This qualitative leap in policy approach required a change in internal government organizational practice. From the traditional ghettoization of this policy in a General Directorate or another body with low administrative status and few instruments, its scope of action has been extended to the bulk of the government's administrative apparatus.

These are policies that prioritize the ecosystem approach and the holistic approach to strategies, as opposed to the strictly budgetary approach and single instruments. The holistic perspective transcends the comprehensive perspective, with the latter being little more than the simple sum of all the parts. Reality is conceived from a complex, multidimensional, and systemic perspective, which requires complex responses where the agents of the Social Economy ecosystem (Social Economy enterprises, associations, universities, administrations, financial institutions, and other related entities) interact. This is how multi-year, multi-dimensional plans with interconnections between the different lines of action and the agents of the ecosystem are formed.

This second generation of policies cannot be categorized as fast policies. On the contrary, they show a high level of sophistication and systematization both technically and in their preparation process. There is a shift from a model of policies with a simple design, with little systematization and programming, to a more systematized model, which contemplates a time horizon that is broader than the annual term that is typical of subsidies. Techniques used are those typical of political science, such as master and strategic plans structured with objectives, sub-objectives, axes, measures, criteria, and procedures for monitoring and evaluation, executing agents, etc. Greater technological complexity is incorporated and elements of a qualitative - not just quantitative-nature are systematically introduced. The greater technical qualification of the policymakers involved in public policy, the greater general prioritization of the Social Economy as a field of general public policy by the regional or local government, and the greater budgetary and material availability have contributed to enabling these systematic policies. These last three factors also condition the range of Social Economy policy proposals throughout Spain.

This second generation of policies has also developed public innovation in terms of specific instruments, in addition to the broad impulse plans or multi-year strategies. The new generation of instruments is consistent with the ecosystem and partnership approach to policy. As examples of these instruments, we can mention cooperative spaces (coworking, athenaeums, working-learning-reflection communities, training, and dissemination, etc.), 'territorial poles of economic cooperation', socio-economic promoting agents, networks of consultants collaborating with regional administrations, partnership and participative research with universities, and new social and ethical banking. On the other hand, there are also new Social Economy laws, the social market and the public procurement mechanism in charge (the latter, already possible since the EU Directives of 2014). This new generation of instruments does not replace the instruments of the first generation-rather, it adds to them. 


\section{Discussion: Limits and Policy Implications of the TPSSE}

After several years of deployment, we can say that the new TPSSEs are in a phase of experimentation in various European territories and in Spain in particular. The success of this experimental phase could lead to its replication, adapting it to other territories. In this context, this study aims to feed and contribute to critical reflection and hopes to inspire new strong public policy fostering the SE. As indicated above, the uneven degree of implementation and success of the three TPSSEs studied derives from their specific features, as well as from elements linked to their effective operationalization. The main difficulties encountered by this new generation of policies are described below.

The first group of difficulties is linked to the participatory and partnership approach of the policy.

The second generation of Social Economy policies aims to radically increase social participation. This is done in two areas: on the one hand, to increase the involvement of existing social actors in the process of policy design and implementation; and on the other, to generically expand social participation aimed at social transformation, i.e., to broaden the range of people, groups, and entities that can be involved in the political project of social transformation that is Social Economy policy. Two major risks arise: the first lies in not being able to create the meeting spaces, the interface agents, the information, training, and acculturation needed to mobilize and involve the latter. The lack of confluence of the actors (or families) within the field of Social Economy has undermined, for example, the development of the TPFSSE in Valencia. The second lies in the exclusion of social agents (e.g., majority trade unions or universities) from the partnership network of co-construction of public policy. Finally, there is a limitation linked to the very operation and coordination of participation, and this requires its own methodologies and systematization. Thus, the use of an excessive period of time to channel social participation can be detrimental to the effectiveness of this policy, prolonging the process excessively until it falls out of step with the political speed, which is based on a four-year term. This limitation can be observed when comparing the Barcelona and Madrid cases.

Difficulties linked to the implementation of a mainstreaming approach.

TPSSE conceives SE as a field of public policy, with its own vision and rationality, which must be integrated into the various government public policies. Therefore, adopting this mainstreaming approach implies that Social Economy is understood as a strategic action field, which is a field in itself, and also as part of the sectoral areas of government public policy (agricultural, labor, social policy, etc.).

The frame, or political narrative, is essential and occupies a central place in this policy. The awareness and acceptance of this vision by policymakers, SE representatives, and regional and local public administration employees is fundamental. In this respect, an adequate media management of this policy-insofar as the sustainability of the policy is linked to the maintenance of the government's political pact on the matter-and the mobilization of different information and awareness-raising mechanisms are key.

A major risk is the emergence of actors who hinder the process by discrediting and questioning the SE with a political-cultural discourse that is contrary to the TPSSE. This could affect the sustainability of the policy if a different government were to be elected, as it has happened in Madrid.

The introduction of the TPSSE into the practice of the administrative apparatus and government sector policies encounters various difficulties. The first difficulty lies in the institutional administrative inertia arising from the bureaucracy of the various administrations involved, as this inertia that can decrease the effectiveness of that change process or even paralyze it, if that bureaucracy obstructs the policy. The second difficulty lies in the possible overlapping, lack of coordination, and misguidance of the multiple administrative bodies mobilized for this policy. The third difficulty is the possible inconsistencies between the different policies in which the Social Economy policy is immersed.

Another important limitation is the necessary sensible and appropriate economic and financial management of this policy, in addition to the necessary budgetary allocation to the goals sought. A policy of this type cannot be deployed with a meagre budget, as has been the case in Valencia.

In short, for this new approach to public policy mainstreaming to be effective, four conditions must be met. First, the prioritization of Social Economy policy must have a solid political consensus 
from the government or government coalition, which must be reflected and materialized in the main programmatic documents of the legislature. Second, linked to the above, this policy must be integrated and coherent with the policy of the regional/local government of reference, both with its general and sectoral programs. Third, this policy must be led by a specific body in the administration, for example, a specific general directorate or an inter-ministerial commission. This body plays the entrepreneurial role of domestic policy, is the proactive engine and the catalyst for public authority policy initiatives in this field. This is a role that only a public body can play. Fourth, this specific body, backed by the government's political consensus, must be able to involve and mobilize agencies, services, and other entities belonging to the public sector, generating an administrative multiplier effect.

Difficulties in evaluating Social Economy policies.

The classic evaluation of public policies has been based on effectiveness, efficiency, and relevance criteria on instruments and quantitative objectives. Given that this second generation of policies contemplates other objectives with greater qualitative content and of a holistic nature (multilevel and multidimensional) while having a broader implementation horizon, the evaluation methodology must be expanded. For example, Utting [55] proposes qualitative evaluation criteria based on state capacity, policy coherence, participation, and sustainability. However, these criteria have been scarcely experimented with to date.

Other limitations linked to the introduction of the TPSSE framework.

As the framework that legitimizes the transformative orientation of policy from a dual social and environmental perspective unfolds, new obstacles emerge. This happens because, among other reasons, these policies based on an "intermediate institutional level" can clash with established routines (meso level) and even with the economic and social structures and values most deeply rooted in society [77]. Therefore, the problem may arise from the fact that the new framework is not capable of breaking down existing practices, so the deployment of the second generation of Social Economy policies would encounter serious obstacles. From this perspective, one of the policy's essential tasks is to contribute to the dissemination of the habits and routines of the most dynamic actors, with a more innovative perspective on the Social Economy. In this regard, it should be borne in mind that, while economic policy action through incentives and information (often associated with laws) only affects the behavior of actors indirectly (through intentions), policy that seeks to influence the habits and routines of individual agents would have a direct impact on such behavior. However, we should consider that habits and routines have not only an individual but also a collective dimension [78]. This has two implications. Economic policy (e.g., territorial) is given more responsibility over collective values, for example, by promoting new forms of interaction and cooperation between actors, which can generate greater trust between them and new relational routines [21,79]. In this way, economic policy defines, through routines, a deeper field of institutional action that is part of a longer-term temporality and contributes to the formation of a coherent political-economic discourse [78] or a new framework for policy [3]. An essential element is that this work of promoting the formation of new routines (which will define a path from below that is consistent with transformative framing itself) must be based not on laws or other formal institutions but on specific policies and actions capable of directly and indirectly influencing the formation and alignment of different public, private, and Social Economy actors.

The framework of transformative change of the second generation of Social Economy policies is based on new routines and values already promoted in the territory largely from outside the SE.

Both theoretically and empirically, it is necessary to complement the perspective of limitations with a perspective that considers the possibilities and implications that are open to politics as a consequence of the previous changes in the routines of a territory.

In many Spanish regions, the complementarities and synergies defined by a framing that places participation and inclusion at the heart of sustainable development between SE market and non-market entities have begun to take shape. They are reflected, for example, in the creation of projects and policies that involve a new alignment of both types of entities for the development of new socio-economic initiatives. The various SE entities would thus begin to align themselves in new, much more diverse, 
and complex ecosystems. But the reality of political initiatives goes far beyond this type of project. It is especially noteworthy how the collaboration of the two families of SE entities (cooperatives and non-profit entities) is beginning to be more than just a resource to give a voice to groups with special difficulties in social and labor integration, etc., to become a way to address general problems of employment, local development, etc., from an inclusive and participatory perspective. The participation of multiple SE entities in the various strategies to create employment and local development in different neighborhoods/districts of the city of Valencia may be an example in this respect [80]. Furthermore, it is also important to highlight the emergence SE entities of a certain size which integrate, within the same organization, the market and the non-market dimension of SE. This is the case, for example, of Caixa Laboral Popular in Valencia. This generates new possibilities to develop cooperation networks with public, private, and mixed actors. It also generates a significant space of influence between this type of entity and other large private companies, for example, in the field of corporate social responsibility. This could be the case with the sponsorship of some financial entities, among others.

In order to understand the new articulating possibilities, both within SE itself and between SE and public and private actors, it is necessary to consider the relationships established between the new framing, the new generation of Social Economy policies and, crucially, the key role of the introduction of new actors (predominantly public) that will essentially promote SE from outside.

The TPSSEs give SE a much broader role in the socio-economic system. This shows that many SE policymakers and practitioners have incorporated the discourse of the Agenda 2030 SDGs, the EU perspective on SE, etc., and the role that all these bodies assign to SE. This has provided support for their actions. Furthermore, these actors have often become the driving force behind the role of SE in society, taking up the challenge of finding specific formulas for the application of this new role in interaction with other actors.

At this point, it is necessary to emphasize that in our perspective of a second generation of Social Economy policies, experimentation takes on a broader meaning than in other approaches. Thus, for example, Schot and Steinmueller [3] stress the great importance of experimentation in a transformative framing of politics as one of its characteristics. These authors link such experimentation to the need to promote disruptive changes in the socio-technical system. Experimentation can also be an essential vehicle through which the leading actors who have promoted SE from different territories have also contributed to the progressive shaping of new habits and routines that are essential for the new framework to become concrete and to be able to deploy it.

This approach converges with that of Schot and Steinmueller [3] in the socially constructed and emerging character of the new policy framework aimed at addressing social and environmental challenges. Indeed, in the new framework, the social and environmental problems generated by the growth model can no longer be solved (as in previous frameworks) by external regulatory actions of the technocratic elites. Rather, they require an emerging co-constructed process of experimentation and learning about the values and assumptions underlying the new framework among a multiplicity of actors [3]. What should be highlighted is that, ultimately, the effective impregnation of the socio-economic system with the principles and values of the Social Economy is an underlying objective of the second generation of Social Economy policies. However, this impregnation will be an emergent process, by virtue of which there is going to be a series of principles and shared values that will not be a "pure replica" of the values of the SE, but rather a set of principles and values that will be specified and decanted chemin-faisant in a concrete way in each territory. These latter principles and values will revolve around the formation of new territorial identities through the interaction between actors, but where the integrating impulse of SE values and principles will be essential to face the new social and environmental challenges. While it is true that many policies often face significant inertia when it comes to being effectively implemented in a way that allows them to take advantage of the potential of the norms or programs to promote SE, the opposite reasoning also applies to a certain extent. In other words, when we argue that the second generation of SE policy involves in part adopting a large number 
of policy initiatives from "outside" SE, this is because the new relationships, behaviors, and values, etc., from new "mainstream" SE policy initiatives have often been tested before, albeit on a smaller scale.

On the other hand, it should be borne in mind that a certain proportion of the reservations about accepting the drive for SE that some new SE laws, programs, and initiatives entail could stem from tensions surrounding the recognition and participation of cooperatives and other SE entities in social dialogue [81]. In this regard, we should remember that, in most Autonomous Communities, SE institutions do not participate-at least not directly—in social dialogue, although they do systematically assert institutional recognition and participation in such dialogue. These Autonomous Communities where SE is not recognized in the social dialogue include those where initiatives have been launched as part of this second generation of SE promotion policies. From this perspective, in many of these latter regions, "general" initiatives to promote SE could face inertia as a significant factor, reflected in the fear of social agents—now, trade unions and employers—-that greater recognition of $\mathrm{SE}$ could affect their position in social dialogue. However, it is also logical to expect that, in many of these regions, new initiatives will be based, at least partly, on a certain well-founded expectation that the majority of economic and social actors could be increasingly receptive to the principles and values of SE. In this sense, we could say that the progressive acceptance by the hegemonic economic and social agents of the importance of SE to achieve their own objectives could facilitate the integration of $\mathrm{SE}$ in social dialogue. This could enhance the cross-sectional penetration of the principles and values of the Social Economy in the productive and socio-economic system.

\section{Conclusions}

Since the beginning of the 2010s, a new generation of public policies to boost SE has been deployed around the world, including Spain and the rest of Europe. In this paper, we name them Transformative Policies for Social and Solidarity Economy (TPSSE); we analyze TPSSEs as a new model of public policy. The aims of our analysis are fourfold. First, we study in which contexts of policy change new PPFSEs emerge. Second, we investigate the contexts in which features of the new wave of PPFSEs are deployed. We then consider whether this new wave is a novel or a transformative model by investigating any differences between these new TPSSEs, and conventional PPFSEs. We conclude by exploring the limits and challenges of these new TPSSEs.

We first attend to the policy change which has enabled these TPSSEs to emerge. The rise of the SE frame has been fundamental in this regard. (At least) four strategic factors are implicated in its advent. First, there is a recent, wider recognition of the very concept of the SE, as well as of the idea that it constitutes a novel realm of public policy. Second, there is a strong narrative that recognizes this new SE frame. Next, we offer theoretical and empirical evidences of the properties of the SE to underlie a robust rationale to argue for a transformative model of development. Fourth, we document the ever-increasing number of public and private think tanks' narratives that spread the SE frame in questions of public policy. Finally, we offer cases of real TPSSE experiences that can be replicated.

Through the study of PPFSE cases in Europe and Spain, e.g., those that take place in Madrid, Barcelona, and the Region of Valencia, key characteristics of case studies in which PPFSE has been deployed in accordance with the theoretical framework of the new wave have been analyzed. Using Chaves' [33] typology of policies, we analyze four new measures that have been deployed during the 2010s. The first measure is the legal and cognitive recognition of the Social Economy as a new public policy space. Another measure is the coordination of public community-partnership mechanisms in the co-construction and co-production of public policy. A third measure is the systematization of socioeconomic policy in the form of long-range strategies. The fourth and final measure is the creation of favorable territorial ecosystems with technical and financial support instruments, as well as privileged access to public administrations' purchases and bids.

We conclude that TPSSE exhibits specific features of a new model, a transformative model of public policy, different than the traditional public policies that foster SE. Firstly, it focuses on transformative change. Secondly, it follows the public-community partnership governance approach. Thirdly, it is 
transversal and mainstream, that is, the introduction of SE policies in a broader policy context, which is into the general and sectoral policies, and finally, it is politically innovative in terms of means and of complex systematization of strategies.

The critical factors in the implementation of these policies are identified. A first group of limitations refers to the difficulties that the participative and partnership-based approach to the policy entails. A second set of limitations refers to the difficulties related to the deployment of the mainstreaming approach. An important limitation is the reluctance to accept and share the frame of the SE of the policymakers, representatives of the SSE, and the regional and local public administration employees. Another set of limitations is linked to the operationalization of the strategy, and to its financial endowment and economic-financial management. Lastly, we can identify difficulties in the systematization of evaluation mechanisms of some fledgling policies that are, to a great extent, medium and long-term policies.

Partly as limitations in the implementation of a TPSSE and partly as limitations of the research itself, it has become evident in the discussion that policymakers need to take into consideration in a broad sense the dynamic or learning effects that are linked to the partnership approach of this new wave of policies. These effects can either slow down such policies or provide an expected ally in the territory. These dynamic aspects, which have hardly received any attention in the literature, although they have been introduced in our article, deserve greater attention in future research.

As limitations of this research, we highlight, firstly, that this study is focused upon selected cases in Europe and Spanish in-deep territorial cases, but it has not addressed the differences in the PPFSE between European countries in terms of their models of the welfare state, industrial policies, or changing policy environments [26,82]. Second, many of the cases studied remain in experimental phases at local and regional levels. Large-scale SE policies have not been deployed yet. The new European Commission has in its new agenda, a five-year European Action Plan for the SE, to take place from 2020 through 2025. In its SE frame, it states that, from a mainstream perspective, SE should be introduced into the different socioeconomic policies of the European Union, as well as into its actions to achieve the Sustainable Development Goals. Both of them are subjects for future research.

Author Contributions: Conceptualization, R.C.-A. and J.R.G.-B.; Funding acquisition, R.C.-A.; Investigation, J.R.G.-B.; Methodology, R.C.-A. and J.R.G.-B.; Writing-original draft, R.C.-A. and J.R.G.-B.; Writing-review \& editing, R.C.-A. All authors have read and agreed to the published version of the manuscript.

Funding: The research reported was partially supported by Grants 55429000 from the Regional Government of Valencia and CES/CSS/2017/03/24131 from the EESC.

Acknowledgments: The authors would like to thank the three reviewers for their comments, which have enriched the final version of the document, and the more than one hundred people who participated in the data collection phase.

Conflicts of Interest: The authors declare no conflict of interest.

\section{Appendix A QUESTIONNAIRE}

Occupation and years of experience of the respondent: $\ldots \ldots \ldots \ldots \ldots \ldots \ldots \ldots \ldots \ldots \ldots$

Institution/Organization: $\ldots \ldots \ldots \ldots \ldots \ldots \ldots \ldots \ldots \ldots \ldots \ldots \ldots$

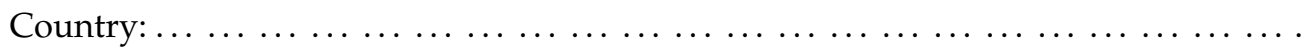

\section{Introduction}

"In the private sector there are numerous organizations and enterprises that produce goods and services to improve people's quality of life or to manage common good that do not correspond to a traditional capitalist business model. The legal form of these organizations and enterprises differs from one country to another, but they often take the form of Cooperatives, Mutual Societies, Associations, Voluntary organizations, and Foundations. These are collectively known as the Social Economy or as the Third Sector of economies. They are mostly based on democratic and participative governance and on not for profit purposes". 


\section{National visibility of the concept of "Social Economy"}

1. Could you tell us whether the concept of "Social Economy" is recognized in your country?

2. Are there any platform or any associative/federative entities that represent the Social Economy Sector as a whole in your country?

3. If it is the case, is there a specific Law or official label to differentiate the Social Economy entities in your country?

\section{Emergent concepts related to the "Social Economy"}

4. Which other concepts related to "Social Economy" enjoy scientific, political, or social recognition in your country?

\section{The "Social Economy"/Third Sector in figures}

5. Please provide us with information regarding aggregate data from your country-number of enterprises, jobs, volunteers, members, turnover- with regard to said institutional forms, preferably to 2015, or as recent as possible.

\section{Public policies aimed at the "Social Economy"}

6. Which is the public authority that officially regulates and promotes "Social Economy" as a whole or, if no available, its major components (as cooperatives or voluntary organizations) in your country? Otherwise, which Ministry is responsible for the Social Economy matters?

7. Could you give 3 examples of 'best public policies fostering Social Economy' in your country deployed by national or regional governments during the 2009-2017 period?

8. Which European Union policies do you think have had more impact on your country' Social Economy during the 2009-2017 period?

9. Could you explain major legal/political barriers against Social Economy entities adopted in the country during the period 2009-2016?

\section{References}

1. Chaves, R.; Monzón, J.L. Beyond the crisis: The social economy, prop of a new model of sustainable economic development. Serv. Bus. 2012, 6, 5-26. [CrossRef]

2. UN General Assembly. Transforming Our World: The 2030 Agenda for Sustainable Development; A/RES/70/1; UN General Assembly: Geneva, Switzerland, 2015.

3. Schot, J.; Steinmueller, W.E. Three frames for innovation policy: R\&D, systems of innovation and transformative change. Res. Policy 2018, 47, 1554-1567.

4. Rao, H.; Greve, H.R. Disasters and community resilience: Spanish flu and the formation of retail cooperatives in Norway. Acad. Manag. J. 2018, 61, 5-25. [CrossRef]

5. Bouchard, M.J. (Ed.) The Worth of the Social Economy, An International Perspective; CIRIEC/Peter Lang: Brussels, Belgium, 2009.

6. Stiglitz, J. Moving beyond market fundamentalism to a more balanced economic. Ann. Public Coop. Econ. 2009, 89, 345-360. [CrossRef]

7. Defourny, J.; Develtere, P.; Fonteneau, B.; Nyssens, M. (Eds.) The Worldwide Making of the Social Economy. In Innovations and Changes; Acco: Leuven, Belgium, 2009.

8. Chaves, R.; Demoustier, D. (Eds.) The Emergence of the Social Economy in Public Policy. In An International Analysis; Peter Lang publishers: Brussels, Belgium, 2013.

9. Utting, P. (Ed.) Social and Solidarity Economy: Beyond the Fringe; ZedBooks: London, UK, 2015.

10. UNRISD. Social and Solidarity Economy and the Challenge of Sustainable Development; UNTFSSE-UN Inter-Agency Task Force on Social and Solidarity Economy: Geneva, Switzerland, 2014; Available online: http://unsse.org/ wpcontent/uploads/2014/08/Position-Paper_TFSSE_Eng1.pdf (accessed on 30 January 2020).

11. Salamon, L.M.; Haddock, M.A. SDGs and NPIs. In Private Nonprofit Institutions, the Foot Soldiers for the UN Sustainable Development Goals; Johns Hopkins Center for Civil Society Studies, WP n. 25: Baltimore, MD, USA, 2015. 
12. UNRISD. Promoting social and solidarity economy through public policy. In UNRISD Flagship Report; UNRISD: Geneva, Switzerland, 2016; pp. 115-139.

13. Lopez, J.L. La promoción de empleos verdes y decentes a través de cooperativas. Boletín Asoc. Int. Derecho Coop. 2019, 54, 115-129. [CrossRef]

14. Mozas, A. Contribución de las Cooperativas Agrarias al Cumplimiento de los Objetivos de Desarrollo Sostenible. In Especial Referencia al Sector Oleícola; Ciriec-España: Valencia, Spain, 2019.

15. Salathé-Beaulieu, G.; Bouchard, M.J.; Mendell, M. Sustainable Development Impact Indicators for Social and Solidarity Economy: State of the Art; UNRISD Working Paper 2019-4; United Nations Research Institute for Social Development (UNRISD): Geneva, Switzerland, 2019.

16. Lee, S. Role of social and solidarity economy in localizing the sustainable development goals. Int. J. Sustain. Dev. World Ecol. 2020, 27, 65-71. [CrossRef]

17. Chaves, R. Politiques Publiques et Economie Sociale en Europe. Le Cas de l'Espagne. Ann. Public Coop. Econ. 2002, 73, 453-480. [CrossRef]

18. Lyons, M.; Passey, A. Need public policy ignore the third sector? Government policy in Australia and the United Kingdom. Aust. J. Public Adm. 2006, 65, 90-102. [CrossRef]

19. Rymsza, M. State policy toward the civic sector in Poland. Int. J. Not Profit Law 2009, 11, 73-85.

20. OECD/EU. Boosting Social Enterprise Development: Good Practice Compendium; OECD Publ.: Paris, France, 2017.

21. Kendall, J. (Ed.) Handbook on Third Sector Policy in Europe; Edward Elgar: Cheltenham, UK, 2009.

22. Tremblay, C. Public Policy Trends and Instruments Supporting the Social Economy: International Experiences; CCRPES Canadian Social Economy Research Partnerships. N²: Victoria, BC, Canada, 2010.

23. Gidron, B.; Bar, M. (Eds.) Policy Initiatives towards the Third Sector in International Perspective; Springer: London, UK, 2010.

24. Alvarez, J.F.; Marcuello, C.; Morais, L.; Radrigan, M.; Sa, J. Anuario Iberoamericano de la Economía Social; OIBESCOOP—CIRIEC-España: Valencia, Spain, 2018.

25. Pape, U.; Chaves-Avila, R.; Benedikt, J.; Petrella, F.; Pielinski, B.; Savall-Morera, T. Working under pressure: Economic recession and third sector development in Europe. Int. J. Sociol. Soc. Policy 2016, 36, 547-566. [CrossRef]

26. Pape, U.; Brandsen, T.; Pahl, J.B.; Pieliński, B.; Baturina, D.; Brookes, N.; Chaves-Avila, R.; Rentzsch, C.; Savall, T. Changing policy environments in Europe and the resilience of the third sector. VOLUNTAS Int. J. Volunt. Nonprofit Organ. 2020, 31, 238-249. [CrossRef]

27. Chaves-Avila, R.; Savall-Morera, T. The Social Economy in a Context of Austerity Policies: The Tension between political discourse and implemented policies in Spain. Voluntas 2019, 30, 487-498. [CrossRef]

28. Millstone, C. Can Social and Solidarity Economy organisations complement or replace publicly traded companies. In Social and Solidarity Economy: Beyond the Fringe; Utting, P., Ed.; Zed Books: London, UK, 2015; pp. 86-99.

29. Reeds, D. Scaling the Social and Solidarity Economy: Opportunities and limitations of fair-trade practice. In Social and Solidarity Economy: Beyond the Fringe; Utting, P., Ed.; Zed Books: London, UK, 2015; pp. 100-115.

30. Snow, D.A.; Rochford, E.B.; Worden, S.K.; Benford, R.D. Frame alignment processes, micromobilization, and movement participation. Am. Sociol. Rev. 1986, 51, 464-481. [CrossRef]

31. Bourdieu, P. Champ du pouvoir, champ intellectuel et habitus de classe. Scolies 1971, 1, 7-26.

32. Fligstein, N.; McAdam, D. A Theory of Fields; Oxford University Press: Oxford, UK, 2012.

33. Teasdale, S. What's in a name? Making sense of social enterprise discourses. Public Policy Adm. 2012, 27, 99-119. [CrossRef]

34. Kingdon, J.W. Agendas, Alternatives and Public Policies; Little-Brown: Boston, MA, USA, 1984.

35. European Parliament. Report on the Social Economy (Toia Report); European Parliament: Brussels, Belgium, 2009.

36. Monzón, J.L.; Chaves, R. Recent Evolution of the Social Economy in the European Union; European Economic and Social Committee: Brussels, Belgium, 2017; Available online: https://www.eesc.europa.eu/sites/default/files/ files/qe-04-17-875-es-n.pdf (accessed on 30 January 2020).

37. Thiry, B.; Vivet, D.; CIRIEC. The Enterprises and Organizations of the Third System: A Strategic Challenge for Employment; CIRIEC: Liege, Belgium, 2000. 
38. Chaves, R.; Perez, J.M. The Social Economy and the Development Cooperation. An International Perspective (La Economía Social y la Cooperación al Desarrollo); University of Valencia Press: Valencia, Spain, 2012.

39. Spear, R.; Defourny, J.; Laville, J.L. (Eds.) Tackling Social Exclusion in Europe: The Contribution of the Social Economy; Routledge: London, UK, 2018.

40. Itçaina, X.; Richez-Battesti, N. (Eds.) Social and Solidarity-based Economy and Territory. In From Embeddedness to Co-Construction; CIRIEC and Peter Lang Publishers: Brussels, Belgium, 2018.

41. Hansmann, H. The Role of Nonprofit enterprise. Yale Law J. 1980, 80, 835-910. [CrossRef]

42. Weisbrod, B. Toward a theory of the voluntary nonprofit sector in a three-sector economy. In Altruism, Morality and Economic Theory; Phelps, S., Ed.; Russell Sage Foundation: New York, NY, USA, 1975.

43. Fraisse, L.; Gardin, L. Les externalités positives dans l'aide à domicile: Une approche européenne. In Les Services Sociaux, Entre Associations, État et Marches; Laville, J.L., Nyssens, M., Eds.; La Découverte: Paris, France, 2001; pp. 192-207.

44. Demoustier, D. La economía social: Una economía privada, colectiva y no lucrativa, activa en la oferta de servicios, en el mercado de trabajo y en el mercado de capitales. Ciriec España Rev. Econ. Pública Soc. Coop. 1999, 33, 29-41.

45. Tomas-Carpi, J.A. The prospects for the social economy in a changing world. Ann. Public Coop. Econ. 1997, 68, 247-279. [CrossRef]

46. Bretos, I.; Díaz-Foncea, M.; Marcuello, C.; Marcuello, C. Cooperativas, capital social y emprendimiento: Una perspectiva teórica. REVESCO. Rev. Estud. Coop. 2018, 128, 76-98. [CrossRef]

47. Gallego, J.R.; Chaves, R. Innovation cooperative systems and structural change. An evolutionary analysis of ANECOOP and Mondragon cases. J. Bus. Res. 2016, 69, 4907-4911. [CrossRef]

48. Gallego-Bono, J.R.; Chaves-Avila, R. How to boost clusters and regional change through cooperative social innovation. Econ. Res. Ekon. Istraživanja 2019. [CrossRef]

49. Palomo, R.; Fernandez, Y.; Gutierrez, M. Cooperative banking and digital transformation: Towards a new relationship model with members and clients. Revesco Rev. Estud. Coop. 2018, 129, 161-182. [CrossRef]

50. European Council. Conclusions; European Council: Brussels, Belgium, 2015.

51. Noya, A.; Clarence, E. Policy Brief on Social Entrepreneurship; OECD/European Union: Paris, France, 2013.

52. Chaves, R.; Monzon, J.L. Best Practices in Public Policies Regarding the European Social Economy Post the Economic Crisis; European Economic and Social Committee: Brussels, Belgium, 2018; Available online: https://www.eesc.europa.eu/en/our-work/publications-other-work/publications/best-practicespublic-policies-regarding-european-social-economy-post-economic-crisis-executive-summary (accessed on 30 January 2020).

53. Saguier, M.; Brent, Z. Regional Policy Frameworks of Social Solidarity Economy in South America; UNRISD Occ. Paper n6: Geneva, Switzerland, 2014.

54. Chaves, R. Las actividades de cobertura institucional: Infraestructuras de apoyo y políticas públicas de fomento de la economía social. In La Economía Social en España en el año 2008; Ámbito, Magnitudes, Actividades y Tendencias; Monzon, J.L., Ed.; Ciriec-España: Valencia, Spain, 2010; pp. 565-592.

55. Utting, P. Public policies for social and solidarity economy. In Assessing Progress in Seven Countries; ILO/International Labour Office (ILO): Geneva, Switzerland, 2017.

56. Monzon, J.L.; Chaves, R. The European social economy: Concept and dimensions of the third sector. Ann. Public Coop. Econ. 2008, 79, 549-577. [CrossRef]

57. Solorzano, M.; Guzman, C.; Savall, T.; Villajos, E. The identity of the social entreprise in Spain: Analysis from four different socioeconomic realities. CIRIEC España Rev. Econ. Pública Soc. Coop. 2018, 92, 155-182. [CrossRef]

58. Lévesque, B. Économie sociale et solidaire et entrepreneur social: Vers quels nouveaux écosystèmes? Rev. Interv. Écon. 2016, 54, 1-44.

59. Fajardo, G.; Alzola, I. Las cooperativas de emprendedores y su contribución al emprendimiento en economía social. CIRIEC-España. Rev. Jurídica Econ. Soc. Coop. 2018, 33, 145-184.

60. Bourbousson, C.; Richez-Battesti, N. Caractériser les PTCE par l'analyse processuelle. Rev. Int. l'économie Soc. 2017, 347, 57-72. [CrossRef] 
61. Mendoza, J.; Roman, C.; Hernandez, M. Social Economy and Public Procurement: The reserved procurements tool. CIRIEC España Rev. Econ. Pública Soc. Coop. 2019, 97, 213-244. [CrossRef]

62. Bastida, M.; Vaquero, A.; Cancelo, M.; Olveira, A. Fostering the Sustainable Development Goals from an Ecosystem Conducive to the SE: The Galician's Case. Sustainability 2020, 12, 500. [CrossRef]

63. Chaves, R. La segunda generación de políticas de fomento de la economía social en España y en la Comunitat Valenciana. Un primer balance. In La Economía Social en la Comunitat Valenciana: Regulación y Políticas Públicas; Fajardo, G., Chaves-Avila, R., Eds.; Ciriec-España: Valencia, Spain, 2019; pp. 19-27.

64. Chaves, R.; Savall, T. Las políticas públicas y las estructuras de apoyo a la economía social valenciana. In Libro Blanco del Cooperativismo y de la Economía Social en la Comunitat Valenciana; Chaves, R., Julià, J.F., Monzon, J.L., Eds.; Ciriec-España: Valencia, Spain, 2018.

65. Consejo Valenciano del Cooperativismo. Plan 'Fent Cooperatives'. 2017. Available online: http://www.gvaoberta.gva.es/documents/7843050/162503991/Plan+de+apoyo+y+fomento+del+ cooperativismo+de+la+Comunitat+Valenciana+2018-2019.pdf/b161a7b2-c487-4587-9912-bf73bfcb4fee (accessed on 30 January 2020).

66. Chaves, R.; Julià, J.F.; Monzon, J.L. Libro Blanco del Cooperativismo y de la Economía Social en la Comunitat Valenciana; Ciriec-España: Valencia, Spain, 2018.

67. Chaves, R.; Monzón, J.L. The social economy facing emerging economic concepts: Social innovation, social responsibility, collaborative economy, social enterprises and solidarity economy. CIRIEC España Rev. Econ. Pública Soc. Coop. 2018, 93, 5-50.

68. Ayuntamiento. Estrategia Municipal de Economía Social y Solidaria del Ayuntamiento de Madrid (2018-2025); Aquo-Dinamia-Tangente-Ayuntamiento de Madrid: Madrid, Spain, 2018; Available online: https://www.madrid.es/UnidadesDescentralizadas/UDCObservEconomico/CarpetaEspecialInformativo/ Actividades\%202018/ESTRATEGIA_MUNICIPA\%20DE\%20ESS.\%20DEFINITIVO.pdf (accessed on 30 January 2020).

69. MARES. Mares de Madrid. Memoria Final 2016-2019; Mares de Madrid: Madrid, Spain, 2019; Available online: www.maresmadrid.es (accessed on 30 January 2020).

70. Ajuntament. Pla D'impuls de L'economia Social i Solidària; Ajuntament de Barcelona: Barcelona, Spain, 2016. Available online: https://ajuntament.barcelona.cat/economia-social-solidaria/sites/default/files/Pla\%20d\% 27Impuls\%20ESS.pdf (accessed on 30 January 2020).

71. Chaves-Avila, R.; Via-Llop, J.; Garcia-Jane, J. The Public Policy Fostering the Social and Solidarity Economy in Barcelona (2016-2019); Working Paper; UNRISD: Geneva, Switzerland, 2020.

72. Chaves, R.; Serra, I.; Tio, M.J.; Savall, T. Evaluación de Las Políticas de Fomento de la Economía Social en España; Spanish Ministry of Employment: Valencia, Spain, 2011.

73. Marti-Costa, M. Políticas Públicas de Promoción de Cooperativas en España; IGOB-Ministerio de Trabajo: Madrid, Spain, 2010.

74. Chaves, R.; Savall, T. La insuficiencia de las políticas de fomento de cooperativas y sociedades laborales frente a la crisis en España. REVESCO Rev. Estud. Coop. 2013, 113, 61-91. [CrossRef]

75. Mendell, M.; Alain, A. Enabling the Social and solidarity Economy through the Co-Construction of Public Policy. In Social and Solidarity Economy: Beyond the Fringe; Utting, P., Ed.; Zed Books: London, UK, 2015; pp. 166-182.

76. Vaillancourt, Y. De la Co-Construction Des Connaissances et Des Politiques Publiques. SociologieS. 2019. Available online: http://journals.openedition.org/sociologies/11589 (accessed on 30 January 2020).

77. Portes, A. Institutions and Development: A Conceptual Reanalysis. Popul. Dev. Rev. 2006, 32, $233-262$. [CrossRef]

78. Gallego, J.R.; Pitxer, J.V. La política económica territorial o la articulación institucional de diferentes actores, escalas y temporalidades institucionales. In Política Económica Frente al Neoliberalismo: Ensayos en Homenaje a Juan Antonio Tomás Carpi; Bono, E., Sánchez, A., Eds.; Tirant lo Blanch: València, Spain, 2017; pp. 149-161.

79. Montagut, T. The third sector and the policy processes in Spain: The emergence of a new policy player. In Handbook on Third Sector Policy in Europe; Kendall, J., Ed.; Edward Elgar: Cheltenham, UK; Northampton, MA, USA, 2009; pp. 119-139. 
80. Gallego, J.R.; Pitxer, J.V. El nuevo papel de la economía social en las políticas de desarrollo local: El caso valenciano. In Estudio Sobre Análisis Comparado de Las Políticas Públicas de Fomento de la Economía Social en la Comunitat Valenciana, Comunidades Autónomas y Estado Español. La Nueva Generación de Políticas Públicas de Fomento de la Economía Social; Chaves, R., Ed.; Ciriec-España: Valencia, Spain, 2020; pp. $264-287$.

81. Gallego, J.R.; Pitxer, J.V. La economía política de la concertación social territorial en España y la inclusión/exclusión de la economía social en un contexto de crisis. Análisis especial de los Pactos Territoriales en el País Valenciano. CIRIEC España Rev. Econ. Pública Soc. Coop. 2012, 76, 127-157.

82. Chaves, R.; Zimmer, A. (Eds.) The Third Sector in Spain and in Europe (El Tercer Sector en España y en Europa); University of Valencia Press: Valencia, Spain, 2017.

(C) 2020 by the authors. Licensee MDPI, Basel, Switzerland. This article is an open access article distributed under the terms and conditions of the Creative Commons Attribution (CC BY) license (http://creativecommons.org/licenses/by/4.0/). 